\title{
Review Essay: Past Practices-Ethnography and American Religion
}

\author{
Courtney Bender
}

Henry Goldschmidt, Race and Religion among the Chosen Peoples of Crown Heights (New Brunswick, N.J.: Rutgers University Press, 2006).

Pamela Klassen, Spirits of Protestantism: Medicine, Healing, and Liberal Christianity (Berkeley: University of California Press, 2011).

Paul C. Johnson, Diaspora Conversions: Black Carib Religion and the Recovery of Africa (Berkeley: University of California Press, 2007).

I.

In the eighth chapter of the Book of Jerry Falwell, the anthropologist Susan Harding recounts her strange day at the "Museum of Earth and Life History." The museum, since closed, occupied an ad hoc space in a Liberty University laboratory building. As Harding notes, it also appeared to occupy the imaginative "space of a museum of natural history." Harding spent a day taking in the "dioramas, explanatory displays and fine-print texts" that explain a creationscience view of natural history. ${ }^{1}$ At first confident about what these exhibits would say, Harding becomes more and more unsettled as she reads the fine print. At least one of the museum's exhibits, one that contains a fragment of Noah's diary, was winking at her. Or, she asks worriedly, "did it blink? Or, God forbid, was it a parody of a wink? Or an imitation of a parody of a wink?" She was uncertain. "What started out as a moment of interpretive discomfort rapidly disintegrated into a state of epistemic shock." ${ }^{2}$ Not willing to remain in this state of discomfort, Harding asked the curator. And he admitted, yes, the exhibit is a joke.

It is perhaps not so surprising that Harding introduces us to a winking museum, given that her book is best known for its unsettling

Religion and American Culture: A Journal of Interpretation, Vol. 21, Issue 2, pp. 259-276, ISSN: 10521151; electronic ISSN 1533-8568. () 2011 by The Center for the Study of Religion and American Culture. All rights reserved. Please direct all requests for permission to photocopy or reproduce article content through the University of California Press's Rights and Permissions website at http://www.ucpressjournals.com/reprintinfo.asp. DOI: 10.1525/rac.2011.21.2.259. 
first-person description of how Harding's secular, anthropological speech became inhabited with the words of a fundamentalist preacher. But that said, the Museum of Earth and Life History is not the only winking museum in America. On an unremarkable Los Angeles street, the writer and critic Lawrence Weschler similarly found himself in the midst of a puzzling set of displays, dioramas, and texts at the Museum of Jurassic Technology. Closely reading the texts that accompany exhibits of bats that fly through walls, a diorama depicting the life and death of a little known operatic soprano, and other curios, Weschler asks, "What is this place?" Like Harding, he approaches the curator, a man named David Wilson, for an answer. Wilson is happy to offer one and hands Weschler a transcript to the museum's "visitor activated slideshow" that explains the museum's purpose and its history and its place within the history of museums. This is not quite the answer that Weschler expects: "at times stupefyingly specific, at other times maddeningly vague," it only prompts further questions and further unsettling. Every time Weschler thinks he has it figured out, the museum winks again. When he says to a colleague, "This is the most incredible piece of performance art I've ever seen'" she reportedly replies, "'What makes you think it's a performance? David believes all this stuff."'3

\section{II.}

What do these vignettes have to do with ethnography and the study of American religion? They are, admittedly, odd beginning points, far from the consolidating center of ethnographic research in American religion. Only one vignette is from an academic book, and only one is about religion, properly speaking.

For most readers of this journal, and for most of the scholars within the field of "North American Religions," studying American religion means writing about the past-that is, writing history. We undertake this study, furthermore, with clear view that the people we write about often have off-kilter relations to "secular history." Our stories are the stories of Americans who live in God's time, the kind of people who have apocalyptic visions and who use ritual, text, and memory to condense and expand time and history in all kinds of redemptive and dystopian directions. They are also the people who actively link their religion to the concept of America itself and the special place in a trajectory of human history that America provides to itself. In many respects, scholarly work on American religion is invested in this dynamic of multiple sacred times and the practices that accompany them. Increasingly, this is fertile territory for deep 
and sustained critical analysis of the process of writing history itself, as some recent work has vociferously argued. ${ }^{4}$

Ethnographic methods would appear to be excellent tools with which to explore the complicated dynamics of how religious Americans live in and through history, both religious and otherwise, especially given the attention that ethnographers have paid of late to the ways that "secular" history is articulated in and made real in social contexts through specific rituals, technologies, and collective memories, as well as linguistic patterns and narrative forms that embed causality and temporality. Ethnographic methods appear to be well suited to help us analyze how people "believe this stuff"- the "stuff," in this case, being our place in the world and in time. Moreover, given that these methods press scholars to investigate how time is practiced (by ethnographers, historians, scholars, and other nonscholar "moderns"), ethnographic methods have the ability to open up a range of questions about how we represent our field (as a matter of the past) and our subjects (as makers of those pasts). With this in view, ethnography can contribute creative as well as critical articulations of "American religion" as a set of intersecting temporal projects.

That said, the focus of most recent ethnographies in American religion lies elsewhere. A full survey of recent monographs would highlight a range of interesting and important thematic foci, each worthy of its own review essay. Studies of religious practice and production "outside" of religious organizations, ${ }^{5}$ of religious discourse and hermeneutic practices and their consequences for civic life, ${ }^{6}$ of transnational processes that open up important ways to understand the shifting spatial and national space of American religion, ${ }^{7}$ and studies of embodied religiosity ${ }^{8}$ all have their important place. A review of these ethnographies would, likewise, most certainly highlight the remarkable degree to which ethnographers and nonethnographers of American religion share topics, themes, and questions in common. We might note that the most recent developments in the field of American religious studies has been a flourishing of ethnographic studies that are grounded in an epistemology shared by ethnographers, historians, and literary and culture studies scholars alike. This shared ground is an accomplishment worth noting.

Yet, there are ethnographic methods and approaches that might be more difficult to reconcile within the episteme that we share. And there are those winking museums that remind us of this. The museums that wink reorient our attention toward ways of analyzing and representing how people live in time that move in different directions. Given those winks, and given my own recent forays into investigating American spiritual practices, this essay reviews three books 
that contribute to our understanding of how Americans practice the past and, moreover, raise questions about how to best represent those practices within scholarly frameworks that likewise are invested in reproducing particular representations of the past. As such, these volumes move beyond merely "shocking" readers into recognition of multiple pasts and, as they do, invest and broaden our shared understanding of how Americans feel, experience, and believe the timesand the histories-that they do.

The three books reviewed here begin with quite different questions about very different subjects (blacks and Jews in Brooklyn, diasporic Garifuna religious practitioners, and liberal Protestant missionaries and healers). Despite these differences in topic, and different approaches to and uses of ethnography, all three place considerable attention on how practices of the past form contemporary groups' identities, particularly as they are shaped within and against American identities and narratives. Each employs ethnographic analysis (including both interviews and observation over time), although, while Henry Goldschmidt's volume is more classically ethnographic, focusing primarily on the contemporary case, both Paul C. Johnson and Pamela Klassen's monographs integrate historical and ethnographic analysis. These differences noted, each shares an interest in representing the living practices of contemporary people in ways that prompt readers to hear and consider how various pasts are believed, acted upon, and reproduced; this includes, in no small measure, consideration of how, in each case, "secular time" figures in those beliefs and sensitivities as well.

III.

Henry Goldschmidt's Race and Religion among the Chosen Peoples of Crown Heights is anchored by the public and widely reported violence between Jews and Blacks in Brooklyn, New York, in August 1991. The violence, variously described as "riot" and "pogrom," took shape in the aftermath of a car accident in which the Hasidic Lubavitcher Rebbe's motorcade struck two black children, killing one and injuring the other. Protests, marches, a murder, widespread looting, and the eventual intervention of the New York Police Department were widely covered as a confrontation between "Jews and Blacks." And, as Goldschmidt notes, community activists and other parties working to smooth over relations between the groups after the fact also worked with this vision of the confrontation in view. Everyone in these groups noted that the two "groups" had different interpretations of the events, including ideas of who was culpable and why. But 
as Goldschmidt makes clear, differences were not that simple or clear cut. Indeed, Jews and Blacks appeared to have very different understandings of the events as events. What was at stake was not the interpretation of the event but its very status as an event.

Goldschmidt's project thus poses the question explicitly: how does (and should) an ethnographer depict or represent an event that, as he notes, has no shared "story"? The relevant parties in the story, blacks and Jews, do not agree on what happened in Crown Heights or why the events took place as they did. Every word used to describe the violence in Crown Heights marks a person's relation to the event and, thus, to one of two groups. Jews called the violence a pogrom while blacks called it a riot; it is fair to say that the experience of those events and their unfolding were shaped by those motifs as well. So, while some residents believed that racial and economic disparities galvanized the events, others believed religious discrimination and hatred were the fuel: riot and pogrom. Goldschmidt argues that recognizing that these interpretations are not secondary glosses on an underlying shared conception of the event but are, more radically, stories of different events is necessary to understanding both what happened in Crown Heights in August 1991 and how religion and race "work" in the aftermath.

With this set of issues in play, Goldschmidt further explores how these two events are built upon and likewise connect Crown Heights residents to religious and racial identities. Goldschmidt notes that the distinction, "Black or Jew," is complicated at the outset by the range of both Jews and blacks in the neighborhood. Orthodox, Hasidic, nonpracticing Jews, black Orthodox Jews, Black Israelites, African-Americans, and Afro-Caribbean Rastafarians defy the gloss of black and Jew as distinct presences on the streets of Crown Heights. Furthermore, Goldschmidt observes, in Crown Heights, having a "religious" or "racial" identity means elaborating a sense of one's place through narratives of lineage, descent, and chosenness that are rarely either "racial" or "religious." Black and Jewish understandings of themselves, told in narratives, expressed through dress, rituals of recognition on the street, and in responses to violence show how both racial and religious practices operate in conceptions of Jewishness and Blackness. Goldschmidt illuminates these links through noting how many different Crown Heights residents view themselves as "chosen people," that is, inheritors of biblical narratives and claims to specialness. Whereas Lubavitcher Jews mark genealogical, traditional, and even spiritual-racial connections between their Brooklyn community and the ancient Israelites, so do the small number of Black Israelites who claim that they are the real inheritors of the tradition 
and that the Lubavitchers are the "fakers." Other black groups accept other narratives of their own chosenness that resonate with the biblical Exodus story. Goldschmidt observes that, for many Black residents of Crown Heights, even those "who have no real interest in being 'Israelites' . . . are nevertheless certain that the 'real Jews' were Black." ${ }^{\prime}$

Race and religion are both "historiographic tools—techniques for suturing oneself to history," Goldschmidt observes. History, in this case, means the history of a religious group and also American history. Jewish and Black identities in Brooklyn are made sensible to those who have them insofar as they are connected to an American urban milieu that, through interactions with various actors (police officers, social workers, community activists, journalists, co-religionists), affords dignity to particular kinds of (religious, cultural, racial) difference, but not to others. Religious and racial narratives are, thus, both constrained and bolstered not only through communities' own interior sense of their own lineage or "past" or lines of racial descent but also through interactions within the secular multicultural and multireligious American frame, which creates various possibilities for recognition. The violence in Crown Heights and its aftermath-the stories of potlucks and daily interactions where residents consider their connections and their distinctions-allow Goldschmidt to observe just how much the secular frames of identity politics reverberate with intersecting claims to sacred pasts. In choosing at the outset to resist an analysis where Jews and Blacks "interpret" an event differently and, instead, to focus on how two "events" live on in Crown Heights memories, Goldschmidt opens up a range of further interpretive potentials that take seriously the ways that various pasts and histories are mobilized and made real in both secular and religious New York.

Paul C. Johnson's Diaspora Conversions similarly focuses on practices that suture people to histories in his study of the religious worlds of the Garifuna, a diasporic Caribbean group with communities in New York and Honduras. Johnson's stated goal is deceptively simple: to analyze how Garifuna religion changes in the wake of and the continuation of diaspora, in this case, a diaspora that brings shamanic practitioners into an urban American milieu where those practitioners meet and come to interact with Yoruba, Santeria, Voudou, and other "Caribbean" spirit traditions and practitioners. Johnson travels and spends time with Garifuna in New York and in Honduras, experiencing and observing ritual events, tracing the interactions of spirits and people who develop new interactions in these new transnational locations. Ancestral spirits in Honduras call 
on sick individuals in New York to return to Honduras to perform expensive and elaborate rituals; "new" African spirits begin to visit the shamans working in New York, encouraging them to "remember" the African homeland of the Garifuna that is absent from Honduran shamanic practice and collective memory.

The Garifuna, Johnson tells us, are black Caribs who have experienced a double diaspora. In the late eighteenth century, free blacks on St. Vincent Island were forcibly relocated to coastal Honduras. Garifuna diasporic religion in Honduras took shape as the linguistically distinct, racially "black" group interacted with the Spanishspeaking Hondurans; they participated nominally in Catholic practices but also cultivated rituals and rites that were oriented around spirits and the memory of the St. Vincent homeland. In the wake of dwindling economic opportunities in the late twentieth century, large numbers of Garifuna migrated to New York and cultivated a different horizon of religious memory in this second diaspora. They do not merely inscribe themselves as the next iteration of a line of Garifuna moving from St. Vincent to Honduras and now New York; rather, they extend their group's relevant pasts back in time to an African origin -in ways that displace the ancestors of St. Vincent and (it seems) the authority of Honduran shamans, whose spirit ties remain connected to that place.

If, as Johnson notes, diaspora cultures are "memory performances of place, staged in a space," it is likewise true that place comes to matter through rituals of articulating and recalling different kinds of past events, more and less distant in time, and more or less present in the demands that they make on practitioners. ${ }^{10}$ As Garifuna practitioners and shamans learn how to translate their work to the New York context with the assistance of Yoruba, Santeria, or Voudou practitioners, they also learn, simultaneously, how to practice within the logics of urban American multiculturalism. The project of reclaiming African pasts provides resources for Garifuna shamans to articulate the shared past of both Garifuna and African diasporic religion. The relation of Garifuna to Africa is unsteady, New York Garifuna shamans realize, yet experiencing an African homeland presents opportunities for practice and power in the city that an Honduran (or St. Vincent homeland) cannot. These changes reverberate in Honduras as well. Johnson notes that the most elaborate rituals (week-long affairs) of Garifuna tradition are becoming more common, as spirits in Honduras have increased their demands on New York immigrants to return to Honduras to perform them. New and old spirits compel different kinds of memories, and different frames of history, into conflict.

Johnson nonetheless notes that it is the New York version of tradition that has "the potential to endure and become paradigmatic." 
Shamans in New York have better access to, and are developing their tradition within, a cultural and political setting where pasts matter and are fitted into secular American histories of multiculturalism. Garifuna religion, "formatted in books and conferences . . . monuments, and routinized orthodoxies of ritual procedure, can also be disseminated, mission-style, from the new diasporic centers back to the homeland, and beyond."11 The distinct narratives of Garifuna pasts, tightly coupled to geographically marked and experienced understandings of Garifuna identity, are not merely different renditions of the same collective memory. They are, rather, competing claims about the past that hold markedly different relations to the textual and media practices that produce and sediment secular history. This secular, historical narrative of diaspora is not in disputeno one doubts that the Garifuna were displaced in the early nineteenth century, nor is there much dispute that the Garifuna were likely descendents of Africans transported against their will to the Caribbean (even if the details are murky). The question rather is one of how the decisive homeland matters as Garifuna in New York make a place for themselves in American society.

Johnson meditates on the question of how to narrate Garifuna history so as to convey best the power of these shifting origins and the narratives they privilege on those who inhabit them. Reflecting on the Proustian madeleine's capacity to reactivate memories, he nonetheless notes, "The arbitrariness of that moment and place that were the prism of remembrance haunts the story.... Suppose other places and objects had appeared, or had been chosen, as the brokers of reminiscence. Might they have opened different avenues of memory and forgetting? Might they have called other souls, with different itineraries, to mind? I think so. . . . Different positions and materials, or even the 'same' objects positioned differently evoke varying constellations of the past." 12 These questions, Johnson's text suggests, extend not only to Garifuna but also to those who write history. While the beginning point is arbitrary, the constellation of the past that it evokes is not.

In both Johnson's and Goldschmidt's ethnographies, American secular practices and institutions play a role in shaping the "constellations" of the past that matter to religious people. As such, "history" is less a backdrop on which events take place than an active dynamic of its own. Several events in both books show these dynamics in play. To take one example, Johnson describes how Garifuna practitioners in New York struggle to find adequate space in which to perform the central yearly ritual welcoming the spirits' return (from St. Vincent). In Honduras, the event is an all-night affair that takes place outside. 
In the New York winter, however, Garifuna need to move the ritual indoors, but large spaces are expensive to rent and laden with restrictions. Eventually, they settle on renting a public school gymnasium for six hours. This compromise is compounded by the school's prohibition of smoke, sacrifice, and alcohol, each a central component of the rites when they are performed in Honduras. Johnson notes that the Garifuna organizers are able to rent the school gym by calling the ritual a cultural event rather than a religious one. A translation of religion into culture, a sleight of hand that is common in New York's multicultural public, has the further effect of bringing non-Garifuna "observers" into ritual space. While the spirits come to the ritual and remain real and powerful actors, they also are effectively situated in a different temporal narrative, where the memory-laden practices of belief, display, and possession are likewise transformed.

Both Johnson and Goldschmidt observe how their subjects fashion religious potentials in America through practices that invoke both religious and secular time. Yet, we can also see that both Garifuna practitioners and the Jews and blacks of Brooklyn have religious histories that stand at some articulated remove from secular history. Their variety of religious traditions, the spirits that ride them, and the lineages of chosenness that they invest with meaning conscientiously stand outside of American history. Religious tradition and American history interact and shape each other, to be sure. But at the same time, their volumes cannot help but raise the question: what kinds of religious practices and imaginations are made possible within the shifting practices of secular American modernity?

Pamela Klassen poses these questions in her new volume, Spirits of Protestantism: Medicine, Healing, and Liberal Christianity, which investigates liberal Canadian Protestants' investments in healing and medicine through the twentieth century. Klassen notes in her preface that her project was originally conceived with a focus on the range of healing practices and interests in health within contemporary liberal Protestantism. As she began fieldwork and encountered people doing yoga, Reiki, and therapeutic touch, as well as investing in healing prayer and parish nurses, she began to consider the ways that contemporary Protestants understand their own religious tradition in relation to these multiple healing practices. Likewise, she also began to consider how modern Canadians' views of their missionary forebears' healing projects simultaneously inspire contemporary practices and impart reason for concern and censure.

Klassen's initial ethnographic questions were, thus, invested with questions about the past and of history, exploring how contemporary Protestants understand earlier Protestants (or earlier modern 
healing programs) in relation to their own healing today and how earlier Protestants (and contemporary Protestants) find various kinds of religious powers accessible to them within medicine and healing. Klassen moves to the archives with these ethnographic, anthropological questions in sight, and they shape her analysis of early twentiethcentury Protestant efforts to channel or expose the power of God's healing through scientific tools, concepts, and methods.

The "relations of Protestants and medicine were often so intertwined and naturalized as to be almost invisible," Klassen writes, noting that, for most of the twentieth century, liberal Protestants in Canada envisioned no necessary or clear distinction between Protestant medicine and secular medicine, between Protestant history and secular history. In contrast to the Garifuna, blacks, and Jews of the other books reviewed, these Protestants did not experience or conceive of themselves as in need of "suturing" to the past. The limited distinction between Protestant religious and secular time is encoded, Klassen notes, in the very terms "liberal Protestant" or "mainstream Protestant." The latter, in particular, denotes "a rather diffuse variety of Christian traditions with different liturgical, theological, and ethnic practices" that, in its very diffuseness, and openness, does "not necessarily conjure the notion of (or appear to itself as) a discrete tradition." 13 Absent a vision of itself as a "discrete tradition" that stood in counterbalance to something called "history," liberal Protestants primarily worked out their religious projects within what they viewed as secular history. And, in the process, their activities and sensibilities invested secular time with various enchantments. Klassen's subjects, including missionaries, nurses, ministers, doctors, and scientists, invested technologies such as radios and church newspapers, as well as the Bible, with sacred powers and divine energies.

Secular history and secular medicine shape the site where Protestants come to expand divine healing, to imagine their unorthodox connections to each other, and to emerge as the healers par excellence, coupling both to Christian truths. Klassen notes that these practices are deeply "historical," but in a sense that enables Protestants to craft pasts with new technological means. "Christianity, in all its varieties," Klassen writes in chapter five,

exudes robust historicity through textual, ritual, dogmatic, visual, and storied forms that all draw on the power of the past to assert authenticity. Religious alterity is a persistent, although often sublimated, current in these constructions of "historic Christianity"; the otherness of Jews, Muslims, First Nations peoples, and the mystic East have all shaped Christian self-definitions and practices and continue to do so. 
Anglo-Canadian Christians integrating Asian and First Nations traditions via ritual carry this past while fostering something new. They historicize with the agency to remember, forget, and revive their pasts (or those of others) in particular ways, while they are at the same time more passively shaped by the weight-or support-of tradition. ${ }^{14}$

Foregrounding the historicity of Protestant uses of secular time demonstrates what it means to analyze "the 'social past' . . the political uses to which versions of the past (histories) may be put, the communicative forms these histories may take and the social occasions on which they are disseminated within any particular community." Klassen's Protestants, who find themselves living in history (rather than a tradition or a counternarrative or anything of the sort), nonetheless by that very measure come to enchant that history, apprehending it as "another form of expressive culture alongside myth and ritual," which Klassen investigates in order to understand "what they might reveal about how a particular people inhabit their world."15

IV.

Klassen, Goldschmidt, and Johnson present quite different ways into the question of how religious Americans experience living in time. That is, they approach the question, indirectly or directly, of how it is possible to believe, whether that believing means engaging in and being in secular time, or religious time, or some combination of the two. To our familiar questions about history that focus on ownership and authority (for example, whose history is it?), they add questions about how different kinds of history, memory, and embodied practices make them powerful, productive, and imaginative. As ethnographers, their questions are not whether these histories are more or less real, but rather how the intersections of various pasts, including modern secular pasts, shape the experience that people have of their own religious capacities and identities. In doing so, these authors focus attention on how secular histories are practiced, as well as how they shape (even as they are sometimes shaped by) religious histories. Their approaches do not deny the facts of history; none of the authors here are ready to abandon history as a project. But their questions, about how histories are made into or unraveled as facts, or enchanted with value that moves well beyond their secular imaginaries, necessarily move away from scholarly practices that are more deeply invested in distinguishing between real "history" and religious "tradition."16

Of course, analyses of how Americans live in, experience, and are moved in time are not questions for ethnographers alone. 
Both Klassen and Johnson invest considerable attention to archives and to historical narratives, and a number of recent American religious histories invest considerable attention to similar themes (Grant Wacker's Heaven Below and Amy Frykholm's Rapture Culture are two that come immediately to mind). ${ }^{17}$ Yet, ethnographic methods may be best suited to explore these questions of how people live in time, given that the ethnographer has no necessary disciplinary investment in reasserting one kind of time as being more real than another. While ethnographers can tell secular histories of any religious group or collective, and doing so may at times be useful, ethnography can also do something else. Sometimes, ethnographic approaches to practices of the past will unsettle the given relationships between practice and history that we often draw upon in our shared "American religion" episteme. Unsettling, in this regard, is not conducted for its own sake but in service of understanding how religion works in modern times, and through modern time. As I argue in my recent book, tracing the history of American spiritual practices is important, but, at the same time, it often stands in the way of adequate evaluation of a tradition that lays very different claim to the past. In this case, and I would argue in others, as well, "historical narratives disentangle the various tendrils of spiritual practice, ideology and experience, making the object clear yet in the process obscuring the very institutional and theoretical entanglements that constitute it." ${ }^{18}$ Ethnography can bring attention to the practices of the past, and the past practices, that shape religious subjects-and shape religion as a subject.

V.

The ethnographer's challenge, in other words, rests in a question of how to represent the ways of being-in-time through which people "believe that stuff." This particular analytical and representational burden does not derive immediately from an ethical obligation to our research subjects-that is, it does not derive from a concern that what ethnographers say may or may not unsettle their epistemologies. (Indeed, if the examples in the books above are any guidance, our research subjects are likely already engaging multiple conceptions of the past and will not take ours as in any way threatening or demystifying.) Instead, this ethnographic burden fundamentally derives from our obligations to our own analytical interests and scholarly fields. Given that decisions that ethnographers consciously make about representation occasionally reformulate narrative modes most familiar to scholars of American religion, they also pose questions to the field about the limits of our shared epistemology. 
How much do our stories, ethnographic or otherwise, convey the degree and respects in which people "believe this stuff" and the ways that they do? How do the distinctions between history and tradition, articulated as such and worked out within both religious and academic narratives, on the one hand, provide opportunities for secular enchantments, charges of magic, and powerful potential for cultural translation, or, on the other hand, lead to intractable misunderstandings or violence? Goldschmidt's two accounts of the violence in Crown Heights, Johnson's attention to the shifting origins of and spirits in Garifuna tradition, and Klassen's emphasis on how an apparently absent "tradition" provides entry points to modern Protestant enchantments of medicine and modernity lead us to consider how it is to live within and gain meaning (and sometimes power) in our complicated modernity. To analyze these stories by first translating the "shock" of multiple times into real and less real pasts would be to miss the point altogether.

We can observe the failures that these translations lead to in taking a closer look at the contrast between Susan Harding's and Lawrence Weschler's winking museums. Harding, we recall, finds herself standing in front of Noah's diary and worrying something along the lines of, "They can't really believe this, can they?" The comforting word of the curator quickly returns her to the certainty of the clear distinction between secular time and biblical time, and she then proceeds to use this distinction to distinguish between cosmopolitan and traditional fundamentalists. She writes, "On the one hand, the museum performed the serious reading of the Genesis account of creation that Falwell's more fundamentalist constituency expected.... On the other hand, it performed a parody of science-even creation science-which especially delighted a circle of savvy, highereducated, one might even say more cosmopolitan, post-fundamentalists." Cosmopolitan fundamentalists can, like Harding, self-reflexively distinguish between secular time, a parody, and a myth. They can use the tools of time but are not altogether bound by them. But they do so from within secular time, not the biblical or "imaginary" time that she nonetheless notes others in the community must believe. Harding does not spend much time considering "traditional" fundamentalists, except to suggest that their experience of "epistemic shock" troubled them. But how so? One would imagine, from Harding's account, that most fundamentalists would not be troubled by Noah's diary. They would not observe it as parody of history but as potential history. But, as Harding notes, many of the museum's visitors were similarly unsettled by the exhibit and worked to have it removed. While Harding's account suggests a much broader drama of multiple times 
being worked out in this museum, it also exposes the limits of Harding's sense of time and their effect on her analysis.

In contrast, Lawrence Weschler carries his own sense of immediate epistemic unsettledness through much of his book. By refusing to allow himself or his readers to decide what is real and what is fake in the museum and, instead, focusing on how the museum creates a sensation of not trusting our ability to judge, Weschler's book becomes a meditation on how modern practices shape our belief in things, including our own belief in our capacity to know what is real. Weschler carries this out, in part, by crafting a text that reproduces for readers some sense of his own experience of how questions about reality and authenticity drove his exploration. His book is a textual version of a "cabinet of wonders," linked to yet distinct from the Museum of Jurassic Technology. Read straight through, the book is a straightforward narrative of Weschler's own interests in the Museum of Jurassic Technology. But when a reader begins the book and reads the discursive footnotes in the order and at the moments they are marked in the text, Mr. Wilson's Cabinet of Wonders reveals a complicated and looping narrative structure replete with temporal shifts, imaginative histories, sideline commentaries, and dead ends. The arguments that Weschler makes within the book about the ways that modern people have come to believe modern time, enchant its boundaries, and use that modernity as sources of wonder are supported by a structure of narration that reflects and reproduces some of the social spaces that pressed Weschler into considering them in the first place.

Weschler's project and subject-and audience-are different from Harding's. Neither Weschler nor his subject, David Wilson, is bound to the conventions of academic or religious representations of the past. That said, both are highly invested in exploring the boundary between religious and secular time and how time itself comes to be felt and troubled, experienced and made real, to modern people. In this respect, Weschler and Wilson nonetheless share questions with scholars of religion, including Goldschmidt, Klassen, and Johnson. Weschler's creative and intellectual sensitivities pose a positive challenge for future ethnographic work, namely, how can we align our modes of representation with the various, truly heterogeneous polytemporal worlds that Americans create, live within, and reproduce? What strategies of representation will allow such considerations to be incorporated into analysis?

Pamela Klassen's volume presents one example of a deeply theorized and intellectually stimulating approach to these issues of representation and analysis of past practices. Klassen enters the archives 
with multiple ethnographic sensitivities that she employs in her experience of reading church newspapers and other materials. She reads these documents for their content, to be certain, but also notes that the act of reading has its own effects. Not only do the church newspapers "lead her to other sources," but, in reading them, they also retain the qualities of the "ritual vessels" that they often were within early twentieth-century Protestant healer and missionary networks. Church newspapers presented a principal technology for expanding Protestant communities and teachings and carried, in their circulation, both a confirmation of that expansion and stories of the possibilities for it. Newspapers, along with other technologies (Bibles, letters, radio, electricity), were invested with divine energies. Klassen's sensitive and self-reflexive archival research, and her simultaneous consideration of the communicative, time-bending potentials of that work, develops in deftly written chapters that offer numerous entry points into the questions of how practices of secular time and communication have worked to offer enchanted possibilities to contemporary and past Protestant healers.

In another example, Joshua Dubler deploys an altogether different representational approach in his forthcoming ethnography of religious life in the chapel of a maximum-security prison near Philadelphia. The Chapel is structured around a single week, beginning with Dubler's arrival on Monday at the morning's first bell. Each day is a chapter. Dubler stays close to the goings-on as they transpire, using them to provoke broader and wide-ranging analysis of race, law, and incarceration. The effects of this choice are several; most immediately, the narrative foregrounds the passage of time and the force of its passing on almost every aspect of prison life. Time weighs and acts (though differently) on all of the chapel's sundry inhabitants-prisoners, guards, chaplains, and Dubler himself. It is constantly present: they are all doing time, though in different ways.

In addition, however, focusing on "seven days' worth of ritual and banter through which the men ... pass their time, care for their selves, foster relationships and commune with their makers, among a host of other activities earnest and absurdist, momentous and quotidian," disrupts Dubler's ability to draw from or reproduce the common conventional ways of writing about American prison life and the place of religion within it. ${ }^{19}$ This, he believes, is necessary, given that these conventional narratives are but variations on two themes of American morality stories that he wishes to critique. In standard narratives, prisoners are little more than stock characters, filling in positions in broader stories about redemption and punishment. Dubler notes at the outset how valuable these narratives have been, given that very few 
researchers (himself included) have access to what goes on in prison life on the block. In this sense, conventional narratives offer a way to close the gaps in researchers' knowledge and to present a view of a seamless understanding of the whole. Taking these issues and the limits of ethnographic knowledge as a foundational point in his book, Dubler transforms the narrative of the week into more than the sum of its days. The result is a complex and thought provoking, unsettling analysis of American religion and American freedom. By refusing, in both statement and in representational frame, to tell the "whole story," The Chapel also compels readers to consider deeply how we make choices about what stories to tell, that is, how those who study religion (and those we study) are doing time.

How do Americans do time? How do scholars of American religion do time? How do all of us come to believe the times we live in and experience them as real? How do those times take on the power and efficacy that they do, whether suturing groups to American history, enchanting the secular American story, reinforcing distinctions between modern secular and traditional religious possibilities, or in other ways? The books I have reviewed here do more than wink at these challenging questions. They answer them not only by rendering important analyses of American religious groups and individuals but also by carefully, painstakingly considering the challenges that go along with crafting narratives that allow readers to experience these times as interacting practices, practices that are believed and lived in the most consequential ways.

\section{Notes}

1. Susan Harding, The Book of Jerry Falwell: Fundamentalist Language and Politics (Princeton: Princeton University Press, 2001), 220-21.

2. Ibid., 223-24.

3. Lawrence Weschler, Mr. Wilson's Cabinet of Wonders: Pronged Ants, Horned Humans, Mice on Toast, and other Marvels of Jurassic Technology (New York: Vintage, 1995), 28, 41.

4. See Robert Orsi, "Abundant History: Marian Apparitions as Alternative Modernity," Historically Speaking (2008): 12-16; and Dipesh Chakrabarty, Provincializing Europe: Postcolonial Thought and Historical Difference (Chicago: University of Chicago Press, 2000).

5. For example, Wendy Cadge, Paging God: Religion in the Halls of Medicine (Princeton: Princeton University Press, forthcoming); Lee Gilmore, 
Theater in a Crowded Fire: Ritual and Spirituality at Burning Man (Berkeley: University of California Press, 2010); Marla Frederick, Between Sundays: Black Women and Everyday Struggles of Faith (Berkeley: University of California Press, 2003); and Winnifred Fallers Sullivan, Prison Religion (Princeton: Princeton University Press, 2009).

6. For example, Paul Lichterman, Elusive Togetherness: Church Groups Trying to Bridge America's Divisions (Princeton: Princeton University Press, 2005); and James Bielo, Words upon the Word: An Ethnography of Evangelical Group Bible Study (New York: New York University Press, 2009).

7. Peggy Levitt, The Transnational Villagers (Berkeley: University of California Press, 2001); Alyshia Galvez, Guadalupe in New York (New York: New York University Press, 2010); and Carolyn Chen, Getting Saved in America: Taiwanese Immigration and Religious Experience (Princeton: Princeton University Press, 2008).

8. R. Marie Griffith, Born Again Bodies: Flesh and Spirit in American Christianity (Berkeley: University of California Press, 2005); and Sarah Pike, Earthly Bodies, Magical Selves: Contemporary Pagans and the Search for Community (Berkeley: University of California Press, 2001).

9. Goldschmidt, Race and Religion, 201. It should be noted that Goldschmidt capitalizes "Black" and "Blackness" throughout his book in order to put this identity on equal footing with "Jew" and "Jewish"indeed, this parity is central to the argument of his book. I have followed his capitalization when I paraphrase his book to keep this argument in place; otherwise, "black" is lowercased in accordance with current conventions.

10. Johnson, Diaspora Conversions, 14.

11. Ibid., 230.

12. Ibid., $1-2$, italics added.

13. Klassen, Spirits of Protestantism, 98, 32.

14. Ibid., 175.

15. Eric Hirsch and Charles Stewart, "Ethnographies of Historicity," History and Anthropology 16 (2005): 261-74, quote on 268.

16. Leigh Eric Schmidt, "History and the Historyless," The Immanent Frame, http://blogs.ssrc.org/tif/2011/01/14/history-and-thehistoryless/, accessed March 1, 2011. On the term "imaginaries," see Charles Taylor, Modern Social Imaginaries (Durham, N.C.: Duke University Press, 2004). 
17. Grant Wacker, Heaven Below: Early Pentecostals and American Culture (Cambridge: Harvard University Press, 2001); and Amy Frykholm, Rapture Culture: Left Behind in Evangelical America (New York: Oxford University Press, 2004).

18. Courtney Bender, The New Metaphysicals: Spirituality and the American Religious Imagination (Chicago: University of Chicago Press, 2010), 184.

19. Joshua Dubler, The Chapel (New York: Farrar Straus Giroux, forthcoming). 